\title{
PENDAMPINGAN PENANGANAN IBU HAMIL KEKURANGAN ENERGI KALORI (KEK) MENCEGAH STUNTING DI MASA PANDEMI DESA BARENG KABUPATEN JOMBANG
}

\author{
ASSISTANCE IN HANDLING PREGNANT WOMEN WITH CALORIE \\ ENERGY DEFICIENCY (KEK) PREVENTING STUNTING DURING \\ THE PANDEMIC PERIOD, BARENG VILLAGE \\ JOMBANG REGENCY
}

\author{
Ririn Probowati, Mamik Ratnawati, Monika Sawitri P \\ STIKES PEMKAB Jombang \\ Email: ririn@stikespemkabjombang.ac.id
}

\begin{abstract}
ABSTRAK
Stunting adalah kondisi gagal tumbuh pada anak balita yang disebabkan oleh kekurangan gizi kronis sehingga pertambahan tinggi anak tidak sesuai dengan umurnya Stunting merupakan masalah kesehatan di dunia yang belum teratasi hingga saat ini. Tujuan untuk melakukan pendampingan penanganan ibu hamil KEK agar tidak melahirkan bayi stunting di masa pandemi desa bareng kabupaten Jombang. Metode pendampingan dengan cara memberikan penyuluhan pemberian makan gisi seimbang bagi ibu hamil yang mengalami KEK, memberikan makanan tambahan dan mengadakan pemeriksaan pada ibu hamil yang dilakukan selama 3 x pertemuan atau kunjungan Bersama dengan bidan desa dan petugas gisi puskesmas bareng dengan tetap memperhatikan protokel Kesehatan. Hasil kegiatan ibu Hamil KEK dapat melakukan pengasuhan gisi sesuai dengan kebutuhan gisi pada bumil dnegan baik . semua menerima menerima pemberian makanan tambahan yang berupa biscuit. Ibu hamil terpantau oleh puskesmas dan bidan desa sampai melahirkan. Salah satu kegiatan Dosen STIKES Pemkab Jombang dalam proses pembelajaran, dapat dilakukan dengan Pengabdian Masyarakat yang dilakukan Di Desa Bareng bekerja sama dengan Puskesmas bareng yang menghadirkan peserta lima (5) ibu hamil KEK dengan memperhatikan protokol kesehatan yaitu $3 \mathrm{M}$ ( memakai masker, mencuci tangan, menjaga jarak) selanjutkan akan di tindak lanjuti dengan bidan desa dan tim dosen untuk melakukan pemantauan selama $3 \mathrm{x}$.
\end{abstract}

Kata Kunci : Hamil KEK, Stunting, Pandemi

\section{ABSTRACT}

Stunting is a condition of failure to thrive in children under five caused by chronic malnutrition so that the child's height does not match their age. Stunting is a health problem in the world that has not been resolved until now. The aim is to provide assistance in handling SEZ pregnant women so as not to give birth to stunting babies during the village pandemic together with Jombang district. The mentoring method is by providing counseling on balanced nutritional feeding for pregnant women who experience SEZ, providing additional food and conducting examinations on pregnant women which are carried out for $3 \times$ meetings or joint visits with village midwives and community health center nutrition officers while still paying attention to health protocols. The results of activities for pregnant women with SEZ can provide good nutritional care according to the nutritional needs of pregnant women. all received additional food in the 
form of biscuits. Pregnant women are monitored by the puskesmas and village midwives until they give birth. One of the activities of the STIKES Lecturer of the Jombang Regency Government in the learning process, can be done with Community Service which is carried out in Bareng Village in collaboration with the Joint Health Center which presents participants of five (5) pregnant women KEK by paying attention to the health protocol, namely $3 \mathrm{M}$ (wearing masks, washing hands, keep a distance) will be followed up with village midwives and a team of lecturers to monitor for 3 times.

Keywords: Pregnant KEK, Stunting, Pandemic

\section{PENDAHULUAN}

Stunting merupakan masalah kesehatan di dunia yang belum teratasi hingga saat ini. Diperkirakan 22,2 \% atau 150,8 juta balita di dunia mengalami stunting (UNICEF, WHO, World Bank .2018). prevalensi di kawasan Asia berjumlah $55 \%$ dan di kawasan Afrika $39 \%$, sementara sisanya tersebar di Amerika Utara, Amerika Latin dan Oceania. Di kawasan Asia Tenggara prevalensi stunting hingga tahun 2017 mencapai 25,7 \%. Laporan UNICEF, WHO, \& World Bank (2018) menunjukkan prevalensi stunting pada tahun 2000 mencapai $32,6 \%$ dan telah berkurang menjadi $22,2 \%$ pada tahun 2017. Di Indonesia, prevalensi stunting menurut Riskesdas (2013) mencapai $37,2 \%$ dan telah terjadi penurunan hingga 30,8 \% Riskesdas (2018). Namun angka tersebut jika dibandingkan dengan ambang batas prevalensi stunting menurut WHO, masih berada pada kategori tinggi.

Dinas Kesehatan (Dinkes) Jawa Timur menyebut kasus Stuntig atau gizi buruk di wilayahnya mencapai 27,67 persen pada 2019 .
Angka itu menurun 3,1 persen dari tahun 2018 sebesar 30,8 persen. "Hingga saat ini, masih ada 344.019 kasus stunting di Jatim," kata Kepala Bidang Kesehatan Masyarakat Dinkes Jatim, Vitria Dewi, dikonfirmasi, Jumat, 14 Februari 2020.

Stunting merupakan kondisi gagal tumbuh, gagal kembang yang terjadi pada anak berusia di bawah lima tahun. Stunting dikenal dengan "berbadan pendek", tinggi badannya tumbuh tidak sesuai dengan standar anak seusianya. "Kasus stunting ini terjadi karena kekurangan gizi kronis, disebabkan karena pola asuh anak tidak tepat yang mengakibatkan kegagalan petumbuhan bagi anak," ujarnya.

Berdasarkan data dari elektronik pencatatan dan pelaporan gizi berbasis masyarakat (ePPGBM) per 25 November 2019, ada 2,8 juta balita yang menjadi sasaran guna mencegah stunting di Jatim. Dari angka itu, didapati anak balita yang tinggi badannya sangat pendek, tidak sesuai usia berjumlah 157.717 orang. Kemudian 186.302 anak pendek, 934.177 bayi normal, 1,2 juta bayi proses pertumbuhan 
baik, dan 344.019 balita mengalami stunting. "Artinya, masih ada 26,9 persen balita yang stunting dari 50 persen jumlah total balita yang terdata," ujarnya. Vitria mengajak masyarakat Jatim lebih memperhatikan asupan gizi yang dikonsumsi ibu hamil dan bayi. Mengingat kasus stunting terjadi karena kekurangan gizi bagi bayi, sehingga mengakibatkan gagal tumbuh dan gagal kembang. "Jadi yang paling penting untuk mencegah stunting, ibu hamil harus perhatikan pola makan dengan makanan bergizi," ujarnya.

Meski diterpa pandemi Covid19, angka stunting di Kabupaten Jombang mengalami penurunan 1 persen dibanding tahun 2019. Yakni dari 18 persen menjadi 17 persen di tahun 2020. Hal ini diungkap Kepala Bidang (Kabid) Kesehatan Masyarakat Dinas Kesehatan (Dinkes) Kabupaten Jombang. Vidya Buana. Penurunan angka stunting, menurut Vidya Buana, tak lepas dari gencarnya kampanye pencegahan stunting yang dilakukan Dinkes ke 21 Kecamatan di Jombang. "Intinya stunting itu bagaimana seorang ibu memiliki asupan gizi yang bagus. Gizi bagus tidak harus makanan yang mahal, bahkan dengan ikan-ikan laut juga sudah tercukupi. Kami, melalui tenaga kader ataupun tenaga kesehatan, terus melakukan pendampingan dan pemantauan," ungkap Vidya saat ditemui ruang kerjanya, Jumat (7/8/2020).

Vidya Buana menambahkan, Dinkes akan selalu mereview dan mengupayakan agar tidak terjadi kesalahan dan berpengaruh pada anak, yang seharusnya tidak stunting menjadi stunting. Utamanya, lanjut Vidya, dengan cara pengukuran. Karena kemungkinan di awal, para kader bisa saja ada kekeliruan dalam melakukan pengukuran. "Dinkes juga melakukan penambahan pengadaan-pengadaan seperti susu untuk Ibu hamil, sirup, zink, vitamin C untuk batita stunting, yang akan disalurkan ke 10 Puskesmas. Dengan kasus stunting tertinggi di atas angka 23 persen di Jombang, yang kemudian akan dievaluasi," katanya. Kasus stunting tertinggi di Jombang, papar Vidya, terdapat di lima daerah yaitu Plandaan, Mayangan dan Jarak Kulon Kecamatan Jogoroto, Kabuh, dan Blimbing Kecamatan Kesamben. "Harapannya, Dinkes tetap bisa mengawal dengan baik, dan tidak akan terjadi peningkatan untuk kasus stunting," pungkasnya.

Terpisah, Ketua Ikatan Dokter Indonesia (IDI) Kabupaten Jombang, dr Iskandar Zulkarnain menjelaskan, Stunting merupakan kegagalan tumbuh anak (pertumbuhan tubuh dan otak) akibat kekurangan gizi. Ini diakibatkan kurangnya pemahaman seseorang atau ibu mengenai asupan gizi yang harus tercukupi dimulai 
sejak masa kehamilan. Karena saat kondisi ibu hamil, akan berpengaruh terhadap proses melahirkan nantinya. dr Iskandar menekankan, salah satu solusi agar dapat diketahui tumbuh kembang bayi dalam keadaan baik, maka saat ibu sedang hamil, harus sering-sering melakukan pemeriksaan. "Jika dalam situasi pandemi seperti saat ini, pemeriksaan tidak harus di RS, dokter, Puskesmas ataupun klinik, tetapi bisa juga dilakukan di lingkungan terdekatnya seperti Posyandu," ujar Direktur RSUD Ploso ini saat ditemui di kediamannya, Kamis (6/8/2020). Kualitas asupan gizi saat hamil, lanjutnya, akan mempengaruhi kondisi bayi mulai usia $0-6$ bulan, 7-11 bulan, dan 12-24 bulan.

Salah satu kegiatan Dosen dalam pengabdian masyarakat membatu menyelesaikan masalah kesehatan yang dialami oleh masyarakat Jombang khususnya ibu Hamil KEK di masa Pandemi dengan memberikan pendidikan kesehatan agar termotivasi dalam melakukan pengasuhan ibu hamil dan bayinya kelak saat setelah melahirkan agar tidak terjandi stunting

\section{METODE PELAKSANAAN}

Dalam kegiatan ini dosen Stikes Pemkab Jombang terlibat dengan bergabagi komponen yaitu tenaga gisi puskesmas bareng, tim penggerak PKK desa dan kecamatan, ibu hamil, kader dan masyakat di sekitarnya aktif berperan dalam memberikan kesehatan dan informasi terkait kebutuhan gizi ibu selama hamil. Pengabdian masyarakat ini mengangkat tema "Pendampingan Penanganan Ibu Hamil KEK untuk Mencegah Stunting di Masa Pandemi Desa Bareng Kabupaten Jombang" Pada Hari Jum'at Tanggal 26 Juni 2020.

\section{HASIL DAN PEMBAHASAN}

Hasil kegiatan ibu Hamil KEK dapat melakukan pengasuhan gisi sesuai dengan kebutuhan gisi pada bumil dengan baik . semua menerima pemberian makanan tambahan yang berupa biscuit. Ibu hamil terpantau oleh puskesmas dan bidan desa sampai melahirkan. Pemantauan di lakuakn Bersama sama dengan Dosen STIKES Pemkab Jombang sebagai wujud pengabdian masyarakat yang dilakukan Di Desa Bareng Kecamatan Bareng Kabupaten Jombang, Sat pemberian penyuluhan menghadirkan peserta lima (5) ibu hamil KEK dengan memperhatikan protokol kesehatan yaitu 3 M ( memakai masker, mencuci tangan, menjaga jarak) yang selanjutkan akan di teruskan kegiatan di bidan desa pada bulan berikutnya untuk memantau Kesehatan ibu hamil

\section{KESIMPULAN}

Indonesia memiliki berbagai macam masalah dalam 
perkembangan gizi seperti Stunting atau balita pendek, pemberian ASI, dan di wilayah jawa timur khususnya di kabupaten jombasng di lingkup kerja puskesmas bareng. Berbagai kendala lainnya yang mengancam keselamatan dan kesehatan anak usia bayi dan balita. Untuk mengatasi hal tersebut perlu adanya upaya pencegahan dari pemerintah, tenaga kesehatan maupun masyarakat seperti pemberian pendidikan kesehatan bagi ibu hamil akan pentingnya gizi dan sosialisasi mengenai dampak negatif kurang gizi bagi masyarakat agar ibu selama hamil tidak mengalami KEK dan pada akhirnya dapat menglahirkan bayi yang stunting

\section{SARAN}

1) Pemerintah, tenaga kesehatan , institusi pendidikan dan masyarakat perlu gencar dalam melakukan perbaikan gizi pada bayi dan balita melalui kegiatan pendidikan kesehatan dan pendapingan bumil KEK sampai, melahirkan . menyeusui ASI ekslusif dan pemberian ASI sampai 2 tahun

2) Meningkatkan kinerja program gizi dengan memperbaiki manajemen perencanaan, pengadaan, distribusi, dan pengawasan bantuan 20 keranga kebijakan 1000 hari pertama kehidupan suplemen tablet zat besi dan pemeberian makan tambahan
3) Bagi Bumil agar lebih berpartisipasi aktif dalam pemanfaatan fasilitas dan pelayanan kesehatan yang ada baik di puskesmas maupun posyandu melalui on linne pada masa mew normal / pandemi covid 19

\section{DAFTAR PUSTAKA}

Adriani, M., \& Wirjatmadi, B.2012.Peranan Gizi Dalam Siklus Kehidupan. Jakarta: Kencana Prenadamedia Group.12.Waryana. 2016.
A., Karima, K.2015. Gizi Ibu dan Bayi. Jakarta: PT Rajagrafindo

Kementrian Kesehatan RI. 2018. Profil Kesehatan Indonesia 2017. Jakarta: Kemenkes RI. Diakses pada tanggal 31 Januari 2019 dari http://www.depkes.go.id/reso urces/download/pusdatin/prof il-kesehatan-indonesia/ProfilKesehatan-Indonesia-tahun2017.pdf2.

Waryana. 2010. Gizi Reproduksi. Yogyakarta: Pustaka Rihama.3.Supariasa \& Hardinsyah. 2017. Ilmu Gizi : Teori dan Aplikasi. Jakarta: EGC.

.KementrianKesehatan RI. 2018. Riset Kesehatan Dasar.Jakarta: Kemenkes RI. Diakses pada tanggal 24 
Januari 2019 dari

http://www.depkes.go.id/reso

urces/download/infoterkini/m

ateri_rakorpop_2018/Hasil\%

20Riskesdas \%202018.pdf5.

Siti Sulastijah, Sumarni DW, Siti Helmyati. 2015. Pengaruh pendidikan gizi dalam upaya meningkatkan kepatuhan konsumsi zat besi melalui

kelas ibu hamil. Jurnal Gizi

Klinik Indonesia Vol 12 No 2

Supariasa, I Dewa Nyoman. 2013.

Pendidikan dan Konsultasi

Gizi. Jakarta: Buku

Kedokteran

ECG.14.Notoatmodjo,

Soekidjo. 2007. 